New Normalcy?

\title{
Consumption and identity
} between reproduction of social inequalities and social transformation in Brazil*

\author{
Thomas Kühn** \\ Daniela Gomes Alcoforado*** \\ \& Miriam Leite Farias****
}

\begin{abstract}
The Covid-19 pandemic has been transforming economic, political and social realities into a so-called "new normalcy". Learning to cope with this contingency requires (re)construction of people's identity. In this study, we critically analyze the narratives of change and the consumption practices of Brazilians interviewed during the period of social distancing. We follow a critical social-psychological approach based on the works of Fromm, Rosa and Kühn. Our results show that the pandemic encourages people to reflect responsibly on their consumption, but also highlight how consumption contributes to the reproduction of social inequality, leading to polarizations within society.
\end{abstract}

Keywords: Pandemic. Social Inequality. Consumption. Identity. Fromm.

\section{Nova normalidade?}

Consumo e identidade entre reprodução de desigualdades sociais e transformação social no Brasil

Resumo: A pandemia do Covid-19 vem transformando realidades econômicas, políticas e sociais, numa chamada "nova normalidade". Aprender a lidar com essa contingência requer (re)construção de identidade das pessoas. Neste estudo, analisamos criticamente as narrativas de mudança $e$ as práticas de consumo de brasileiros entrevistados no período de distanciamento social. Para isso, utilizamos lentes teóricas de Fromm, Rosa e Kühn. Nossos resultados evidenciam que a pandemia estimula as pessoas a refletirem com responsabilidade sobre seu consumo, mas também destacam como o consumo contribui para a reprodução da desigualdade social, levando a polarizações dentro da sociedade.

Palavras-chave: Pandemia. Desigualdade Social. Consumo. Identidade. Fromm.

\begin{abstract}
* Este estudo foi parcialmente financiado pela Coordenação de Aperfeiçoamento de Pessoal de Nível Superior (Capes).
\end{abstract}

** Thomas Kühn
é professor
de psicologia
organizacional
na International
Psychoanalytic
University (IPU) de
Berlim, Alemanha;
diretor do Erich
Fromm Study
Center, na mesma
universidade. Orcid:
O000-0002-8264-
9764.
<thomas.kuehn@
ipu-berlin.de>.
***Daniela Gomes
Alcoforado é
doutoranda no
Programa de Pós-
Graduação em
Administração da
Universidade Federal
de Pernambuco
(UFPE), Recife, PE,
Brasil. Pesquisadora
convidada na
International
Psychoanalytic
University (IPU),
Berlim.

** Thomas Kühn é professor de psicologia organizacional na International Psychoanalytic University (IPU) de Berlim, Alemanha diretor do Erich Center, na mesma universidade. Orcid: 0000-0002-82649764.

<thomas.kuehn@ ***Daniela Gomes Alcoforado é doutoranda no Programa de Pós Graduação em Administração da Universidade Federal de Pernambuco (UFPE), Recife, PE, Brasil. Pesquisadora Psychoanalytic Berlim. 
Orcid: 0000-0002-

1899-693X.

$<$ daniela.

alcoforado@ufpe.

br>.

**** Miriam Leite

Farias é doutoranda no Programa de Pós-Graduação em Administração da Universidade Federal de Pernambuco(UFPE), Recife, PE, Brasil, com período de intercâmbio na Skema Business School, Lille, France. Orcid: : 0000-00023207-9900. <miriamlfarias@ gmail.com>.

\section{Introduction:}

\author{
social change, social inequalities \\ and a "new normalcy"
}

The pandemic revealed structural vulnerabilities in contemporary societies (Crockett \& Grier 2020; Bublitz et alii, 2020, Saad-Filho, 2020). Much like in 2008, many fallacies of neoliberal ideology were exposed by a crisis (Solty, 2020; Briggs et alii, 2020). Worldwide, the effects of the pandemic are triggering an incomparable impact on the lives of more marginalized individuals particularly as it threatens the health and income of the poorest residents of peripheral areas and those who already had fragile ties in the marketplace.

Discussions of social change in contemporary societies must acknowledge technological progress and its consequences for human relations. Though different interpretations are possible, it is an accepted assumption that the digital transformation of our social world is challenging established forms of human interaction, not only between two interacting individuals, but also related to groups, organizations, and institutions. Yet, the manner in which changes in societies are named and summarized is always part of a narrative that highlights certain developments more strongly than others. Change narratives tell a story of a society by connecting the contemporary situation with iconic moments of the past and an outlook into the future. This cannot be seen separated from the political points of view which serve as a frame for those narratives.

In this sense, the current situation highlights the remarkable relevance of social science research. The changes that are taking place so rapidly and so profoundly can be depicted in real time, so that an academic space for resonance and reflection should be created which makes it possible to reconstruct the individual and collective struggle for understanding and power to act under conditions of epistemic uncertainty and thus makes an important contribution to the analysis of the developing "new normalcy". This expression is increasingly used in various contexts, from politics to management consulting, without being clearly scientifically anchored so far. It refers to accelerated transformation processes in the wake of a crisis, which are associated with the fact that everyday life will be fundamentally changed in the long term. Its semantic tail includes an increased relevance of digital technologies in the context of everyday life, for example in teleworking or on-line shopping, but also a changed basic understanding of human relationships after the experience of the normative imperatives of social distancing. However, the concept of normalcy must be questioned in principle from a critical social science perspective, as structural differences and inequalities between different social classes are 
easily overlooked. Fromm (1955), for example, already pointed to the "pathology of normalcy" in the 20th century which he associated with alienated living conditions. It is therefore all the more remarkable that the term "New Normal", in light of the Covid-19 crisis, has become such an important frame of reference in various areas of public debate. Thus Zimmer (2020) points to a "patina of nostalgia" that is associated with the term: "when everyone's life has been so severely disrupted, the old-fashioned awkwardness of normalcy carries with it a retro appeal that is downright soothing". At the same time, Asonye (2020) contends that the danger of a worsening global polarization of rich and poor should by no means be forgotten in debates about the "New Normal".

This makes it all the more important to contribute to a sharpening of the debate on social transformation processes in the wake of the Covid-19 crisis through academic research and to examine to what extent these processes can be understood as a construction of new normalcy, which, like any other construction of normalcy, must also be critically questioned.

Having to come to terms with a "new normalcy" requires identity work from people. Images of sociality are changing during the pandemic, particularly regarding the significance of community and individuality and their relationship to each other. Especially in times of "social distancing", people might experience how much they are social beings and that social relations are a cornerstone of societies. How one relates to oneself and one's social environment, which social groups one feels one belongs to, which ideas of future togetherness are expressed and consolidated in concrete practices of action will have decisive normative significance for the constitution, functioning, and development of post-pandemic societies. How individuals deal with uncertainty, ambiguity and ambivalence on different levels is key for identity constructions, as one must deal with one's own anxiety, fears, feelings of loneliness and mortality.

Therefore, a special focus in this study is on consumption from an identity perspective: different framings and usages of consumption for constructing identity, exploring the ambivalence of consumption between social integration and polarization in the context of the "new normalcy". We focus on consumption as consumer goods do not only have a functional benefit, but they serve as a "representation of desires, ideas, values and ego-ideals" (Voswinkel, 2013: 143). Different styles of consumption are used to convey membership in groups and thus social identity. As the French sociologist Pierre Bourdieu has pointed out, this also involves hidden mechanisms of exclusion (e.g. Bourdieu, 1982). In times of social distancing, consumption plays an important role in order to connect to the social world that has to be taken into 
account and investigated, especially regarding its meaning for dealing with structural uncertainty and the reproduction of social inequalities in contemporary societies.

In this sense, in this article we consider the complex context of an unequal society like Brazil. The cumulative effects of the disease have brutally established new economic and political realities in the country, placing the population in a period of social change and exacerbating existing polarizations. The gap between social classes is growing because of existential burdens on precarious classes. In megacities like São Paulo, the disease already kills more people in the periphery than in the center (Dw, 2020). In the last months, 51\% of the Brazilians of lower classes earning up to $\mathrm{R} \$ 500$ per month have lost half or more than half of their incomes. Approximately 13 million people declared that they had no income during the pandemic. Hence, the crisis accentuates class and regional inequalities (Folha de São Paulo, 2020).

In view of this change and its drastic consequences, the question of how people in Brazil deal with this crisis and what role consumption plays in it is particularly urgent. Despite all the regional particularities that need to be taken into account, Brazil is an example of an unequal country with a capitalist structure in which the role of consumption between the reproduction of social inequality and possible transformation processes in society shall be examined. Therefore, we critically approach the identity construction of the consumers, focusing on subjective interpretations and framings of the crisis (change narratives), asking ourselves which narratives can be distinguished and interpreted from the interviews that can be interpreted from a critical perspective within contemporary capitalistic ideology, exemplified in the Brazilian reality during the Covid-19 pandemic.

\section{A critical perspective on consumption}

Taking into consideration that the normative of social distancing means avoiding personal contacts, the "language of consumption" becomes more important as a means to feel related to the social world. Thus, consumption in contemporary societies is a central mode to relate to the socially constructed environment and relate to others. To this end, it is necessary to focus on the role of consumption on the collective negotiation processes of affiliations and collective identities, which are reflected in individual biographical narratives as a struggle bringing together personal experiences, sociocultural frames of orientation and the new framework for interpretation and action.

According to sociologist Norbert F. Schneider, consumption is a dynamic, multiphase process that begins with the genesis of needs, includes activities of infor- 
mation acquisition and decision-making, extends over the use of goods and ends with their disposal (Schneider, 2000: 11). Stephan Voswinkel points out that no one cannot consume as long as he or she wants to belong to society as a living being (Voswinkel, 2013: 122). In contemporary societies, services and goods have to be purchased on the market so that people act as consumers. The art historian Ulrich Blanché (2012: 10) also understands consumption in this sense as an existential and life-sustaining phenomenon that extends throughout all times. For Blanché (2012: $20)$, consumption is the principal and sometimes the only social action and interaction within the capitalist system and relates to capitalism in the same way as praying to religion. Accordingly, he sees consumption as an act through which the current economic and social order manifests itself (Blanché, 2012: 20). Blanché's view of consumption makes it clear that the examination of consumption is of central importance in order to deal with the conditions of our life in contemporary societies.

Our analyses follow the basic assumptions of Consumer Culture Theory (CCT) and Critical Social Psychology. CCT is a research tradition that seeks to understand the sociocultural aspects of consumption, exploring the construction, modification and maintenance of meanings of consumption (Arnould \& Thompson, 2007). Consumer Culture plays an important role for understanding the construction of personal identity and associations with others in the social space (Bourdieu, 1982; Lury, 1996; Ritzer et alii, 2001). According to McDonald et alii (2017), consumer culture can work as a tool for social categorization in the way that considers how people understand the dynamics of societies and related imaginaries of markets. According to Arnould and Thompson (2015), previous research in Consumer Culture Theory has already investigated how consumers mobilize themselves as collective groups to achieve a higher degree of social legitimacy and an access to new identity resources, as well as social inclusion. For the authors, the work of identity in CCT has recently taken a political ideological concern by understanding the reconfiguration of power relation networks, such as "hierarchical authorities, status systems, loci of exchange, normalized beliefs, dominant categories, disciplinary practices, and social conventions" (Arnould \& Thompson, 2015: 9).

Consistent with this notion, the core dimension of critical social psychology is to contribute to the reconstruction of the symbolically founded establishment of power and inequality relationships (Kühn, 2014; 2015a, Kühn \& Langer, 2020). A prerequisite for this is to look at the cultural framework of everyday life from a social psychological perspective. Dealing with culture means addressing the question of how specific symbols in a society or group are interlinked with one another in order to provide orientation for individual action and biographical trajectories. Critical Social Psychology investigates how people construct membership in different so- 
cial groups and what meaning these constructions of group membership take on for everyday life. Thus, it makes an important contribution to the understanding of contemporary capitalist societies and for a critical engagement within societies.

Critical Social Psychology ties in with the works of Erich Fromm, for whom the critical examination of consumption and culture was of central importance. Fromm's theoretical considerations regarding the significance of consumption for our self-image and our actions towards others are indeed very current and might be even more valuable for debates on the changing relation between human beings and technology today than they were at the time of their publication. Today, they can be related to a development that had in fact commenced during Fromm's lifetime, but has grown in visibility and presence since (Funk \& McLaughlin, 2015; Funk \& Kühn, 2019; Kühn, 2019).

Fromm brought the criticism of consumption to the point in a particularly sharp way. The author associates the predominant way of consumption in modern Western societies with passivity and a basic attitude oriented toward having, which he contrasts with being active in an ideal-typical way. In this context he speaks of "homo consumens" (Fromm, 1968-2010) for whom consumption serves as an alienated form of dealing with one's own existence and society, in which the feeling of self goes hand in hand with the incorporation of things and is dependent on them. In an alienated way, consumption enables people to develop a feeling of freedom that contrasts with the experience of powerlessness and lack of influence in the public sphere. As buyer and consumer, people feel powerful because they can choose between different brands and offers, unaware that "to be the king in the supermarket" is just an expression of "fake freedom" (Fromm, 1968-2010: 123):

But the real feeling of freedom today lies in another sphere, that of consumption. In this sphere everybody except those who live a substandard existence experience the freedom of the consumer.

Here is an individual who is powerless to have any influence - beyond a marginal one - on the affairs of the state or the enterprise in which he is employed. He has a boss, and his boss has a boss, and the boss of his boss has a boss, and there are very few individuals left who do not have a boss and do not obey the program of the managerial machine - of which they are a part. But what power does he have as a consumer? There are dozens of brands of cigarettes, toothpastes, soaps, deodorants, radios, television sets; movie and television programs, and so on and so forth. And they all woo his favor. They are all there 'for his pleasure.' He is free to favor the one against the other and he forgets that essentially there are no differences. This freedom to give his favors to his 
favorite commodity creates a sense of potency. The man who is impotent humanely becomes potent - as a buyer and consumer (Fromm, 1968-2010: 122).

On the basis of a psychoanalytical understanding, Fromm frames compulsive consumption in this sense as compensation for anxiety, which arises from the feeling of inner emptiness, hopelessness, confusion and tension: "By 'taking in' articles of consumption, the individual reassures himself that 'he is', as it were." (Fromm, 1968-2010: 123). According to Fromm, consumption prevents people from becoming aware of their fears and their anxieties, because through the possibility of consumption they develop a feeling that they exist. At the same time, however, it also forces them to keep on consuming, because what they consume creates only shortterm satisfaction.

Markets therefore form an "anonymous authority" (Fromm, 1955: 13), which contrasts with a directly exercised power and control. To the outside world, an anonymous authority has "the appearance of tolerance and compliance", and yet one cannot ignore the claims associated with the authority. According to Fromm, this could have drastic consequences: The fact that people orient themselves in their actions on the one hand to the market and the connected norms of behavior and on the other hand experience their own decisions as free, leads to an alienated self-understanding and to self-exploitation: People identify with purposes that lie outside themselves and instrumentalize themselves as if they were part of a machine.

He framed the emergence of markets and organizations as a contribution to positive freedom, to the development of an active, critical, and responsible self (Fromm, 1941). In this sense Fromm encourages to investigate how consumption can be part of a transformation to a more humane society and how this could be institutionalized within societies. Fromm stresses that this change can only be understood as a bottom-up process - which is why it is important to deal with changing perspectives and meanings of consumption in a changing society:

Such a change would obviously come not as a result of bureaucratic orders but out of studies, information, discussion, and decision-making on the part of the population, educated to become aware of the problem of the difference between life-furthering and life-hindering kinds of needs. (Fromm, 1968-2010: 124).

In this context, he points out the need of human beings to be productive within groups and organizations and to overcome their hidden anxieties. For Fromm, the opposite of consumerism consists in being active and interested in one's own 
and society's affairs. He contrasts the basic attitude of homo consumens, which is oriented toward having, with the orientation toward being: While having is oriented towards things, being refers to experiences (Fromm, 1976). Its most essential characteristic is activity, not in the sense of busyness, but in the sense of an inner activity, the productive use of human powers. Activity, according to Fromm, means to give expression to one's dispositions, one's talents, the richness of human gifts with which everyone is endowed, albeit to different degrees.

Fromm considers human knowledge to be always context-bound and historically conditioned since it is based on previous experiences and is therefore always incomplete. Although human ambiguity can never be completely eliminated, society can become more humane in the context of dialectical processes and "liberate itself from the influence of irrational and unnecessary social pathology" (Fromm, 1969-2013: 10). Consequently, he considers the fate of modernity not sealed (Rosa, 2016: 570), but as shapeable by humanistic planning. People have to be seen as social beings. To be in relation with others is an existential necessity because the individual human being needs others in order to survive. Being related to others provides creative spaces and the possibility to experience resonance in contact with others. According to Fromm, people "must be affectively related to others in order to overcome the anxiety produced by his total isolation" (Fromm, 1969-2013: 6).

The sociologist Hartmut Rosa, whose work explicitly takes up Erich Fromm's basic assumptions and his analyses of alienation (Rosa, 2019), also argues in this double sense. He underlines that consumption is to be regarded as alienated in particular if the consumer cannot establish a further relationship with the object after the purchase, but is increasingly dependent in his experience on the deceptive expectation of achieving increased satisfaction through the increased ability to purchase. In this context, he speaks of a mute world relationship: "We may then have the goods and the possibilities they open up, but they do not answer us" (Rosa, 2016: 430, translation by the authors).

As an antipole, Rosa elaborates the theoretical concept of resonance, which he defines as a form of world relationship formed by affection and emotion, intrinsic interest and self-efficacy expectation, in which the subject and the world touch and transform each other at the same time (Rosa, 2016: 298). With reference to the sphere of consumption, Rosa emphasizes that it is only in the use of goods, in working on and with them, that self-efficacy and consequently resonance can be experienced, i.e. by establishing a relationship with them. Consumption becomes alienated when the act of purchase is confused with the relationship of appropriation or even has to compensate for the lack of resonance. In capitalism he sees 
exactly this danger; that people's desire is increasingly directed toward the acquisition of ever new goods, but not toward the development of a relationship to them.

\section{The identity construction framework}

In an examination of the works of Charles Taylor, Rosa established that identity is based on a culturally mediated and internalized value system, a kind of "moral map" that forms an implicit value horizon. Against the background of this horizon of values we interpret what is important and unimportant, right and wrong, desirable and uninteresting. Identity is therefore not limited to the level of linguistically articulated self-understanding. Instead these unconscious practices can be understood as a form of "embodied self-interpretation" which is crucial for understanding identity constructions. For this reason, the social psychological reconstruction of identity work should not be limited to the analysis of verbally articulated self-images and assessments of one's own person but should be devoted to the everyday life and life history of people.

Identity cannot be freely chosen or arbitrarily changed by consumer decisions. According to the social psychological perspective, the construction of identity has to be understood as an ongoing development process linked to one's own biography, which takes place as identity work in confrontation with the social world (e.g. Rosa, 1998; Keupp et alii, 2002; Kühn, 2014, 2015a; Ehnis et alii, 2015). In line with this understanding, identity is always embedded in a life-historical framework - as a specific subjective positioning that connects the experience of the present with interpretations of the biographical past and imagined future. Identity work addresses the question of who one is, how one believes to have become the person one is and where one wants to go. For this reason, the socio-psychological reconstruction of identity work should not be limited to the analysis of verbally articulated self-images and self-assessments of one's own person but should be devoted to everyday life.

As a synthesis of the approaches of Rosa (1998) and Keupp et alii (2002), Thomas Kühn (2015b) proposed to differentiate identity work on three levels, summarized in the $A B C$ model of identity:

i. Striving for authenticity and coherence: appreciating oneself, experiencing oneself as coherent and genuine, coming to terms with oneself.

ii. Striving for belonging and recognition: to experience oneself as integrated in society and as a valued part of a community. 
iii. Striving for control and responsibility: being able to experience, shape and act effectively.

For our research, this $\mathrm{ABC}$ model of identity (Authenticity, Belonging, Control) forms a basis for investigating the symbolic significance of consumption for identity constructions during the New Normalcy within the first months of the Covid pandemic in 2020. The identity perspective will be used as theoretical ground to analyze and explore the symbolic meanings that individuals give to consumption and to understand how these meanings have changed during the course of the pandemic.

\section{Case study in Brazil: research design}

Following a reflexive understanding of social science (e.g. Kühner et alii, 2016), we initiated our research with qualitative in-depth interviews in early 2020 to investigate how participants of distinct cultural, social and political backgrounds were dealing with the Covid-19 pandemic phenomenon. First of all, the semi-structured, "problem-centered" interviews (Witzel \& Reiter, 2012) referred to a tracking of changes in social perception and related feelings, the sense of belonging, social relations, political attitudes, consumption changes, and measures taken to tackle the pandemic. This involved both the experience of personal everyday life and reflection on one's own integration into the social world as a citizen of the state and the world as well as the responsibility associated with this. During the interviews, we covered topics from identity and forms of socialization to changes in consumption practices and opinions on political and global aspects.

To date we have over 50 interviews with Brazilians who experienced social distancing in the beginning of the pandemic. The interviews had an average duration of 1 hour and 20 minutes and were conducted between April 13th and May 12th, 2020. Respecting the local recommendations regarding the health of the interviewees, all interviews were conducted virtually and were recorded and transcribed with the permission of the interviewees. All respondents agreed to participate in the interview voluntarily and received a privacy assurance in which the researchers guarantee anonymity and protection of the collected data.

The sample consisted of Brazilians who were over the age of 18 and experienced social distancing at the time of the interview. The participants were invited for a voluntary interview through social media and, after the initial interviews, snowball sampling was used (Patton, 2002). According to the principles of theoretical sam- 
pling, we included people from different social classes, genders, ages and lifestyles in order to allow comparisons of cases with maximum and minimum contrast.

The age of the respondents ranged between 20 to 66 years old. Considering a panorama of the Brazilian society, students are included to an above-average extent. Regarding monthly income, the research corpus is diverse. While some respondents had no income at the moment of the interview, others receive more than five minimum wages. Thus, we are able to show a picture of social groups and income distribution inequalities in the country.

For this article, the interviews were compared in terms of references to the importance of consumption for the construction of identity as a thematic analysis (Braun \& Clarke, 2006), following a reflexive basic understanding (Kuhner et alii, 2016; Braun \& Clarke, 2019).

Finally, for the purpose of this study, we selected 15 of these interviews to illustrate our main findings. The profiles of the participants containing information about age, sex, civil state, monthly income during the pandemic, and profession are displayed in Table 1. Fictitious names were created to protect the anonymity of the respondents.

TABLE 1

PROFILE OF THE PARTICIPANTS

\begin{tabular}{|c|c|c|c|c|c|}
\hline $\begin{array}{l}\text { Fictitious } \\
\text { name }\end{array}$ & Age & Gender & Civil state & $\begin{array}{c}\text { Monthly income at the moment } \\
\text { of the interview (R\$) }\end{array}$ & Profession \\
\hline João & 26 & Male & Single & 5.000 & Health Insurance Saler \\
\hline Laura & 52 & Female & Married & 750 & Housekeeper \\
\hline Denise & 26 & Female & Single & 7.000 & Bank Manager \\
\hline Vitória & 60 & Female & Single & 3.100 & Retired \\
\hline Suzanna & 26 & Female & Single & No income & Make up Artist \\
\hline Natalia & 66 & Female & Married & 13.000 & Physician \\
\hline Amanda & 49 & Female & Married & 6.000 & Trade Representative \\
\hline Paulo & 33 & Male & Divorced & 3.400 & $\begin{array}{l}\text { Public employee and president } \\
\text { of a transport cooperative }\end{array}$ \\
\hline Sarah & 28 & Female & Single & 2.200 & Student \\
\hline Elaine & 26 & Female & Married & 4.000 & Student \\
\hline Sofia & 22 & Female & Single & 1.000 & Student and intern \\
\hline Carla & 26 & Female & Single & 2.000 & Student and financial analyst \\
\hline Luísa & 20 & Female & Single & 1.000 & Student and intern \\
\hline Matheus & 23 & Male & Single & No income & Student \\
\hline Roberto & 57 & Male & Married & 11.000 & Public employee \\
\hline
\end{tabular}




\title{
Empirical findings
}

\author{
Authenticity and identity: \\ Consumption and the strive for authenticity \\ between engagement and alienation
}

If we look at consumption during the pandemic in terms of the extent to which it contributes to a sense of authenticity and coherence, a tension between engagement and alienation can be observed. On the one hand, efforts can be identified to reflect more strongly on one's own consumption in the face of change and to contribute to a more sustainable life. In this sense, the feeling of being able to get involved and be an active part of a social change toward a more reflective and healthier lifestyle strengthens the experience of one's own coherence and authenticity. On the other hand, dependence on the consumer sphere becomes a normative reference necessary for maintaining a feeling of self. This corresponds to Fromm's perspective of alienation.

Engaged consumption:

Being part of a change towards a more reflexive lifestyle

Some respondents showed higher awareness of their consumption since they perceived their impact on their environment around them. Student and financial analyst Carla, 26, stated that "today I try to know a lot more about who I'm buying from, who the producer is, trying to buy as close as possible". She stated that she believes that after the Covid-19 pandemic, meat consumption will be more questioned by the population, both in terms of quantity as well as quality and provenance of the product. Similarly, Luísa, 20, stated:

\footnotetext{
I started to buy more from small businesses, before I was more of a mall and department store person, and today I understand that there are people on my side who are there fighting and need the money. I think that the awareness that it is really necessary to buy from small businesses has changed for me (Luísa, 20).
}

Thus, we could see that in a moment of social isolation the shift to a more responsible consumption, allowed some participants to feel active and authentic during the pandemic, responding to the current situation, such as the scarcity of resources. Responsible consumption was a way to take a stand and make a difference.

Furthermore, we conclude that in the world of the interviewees the consumption sphere might appear as a field that strengthens feelings of the self. To experience 
that one is able to select from different offers and make a responsible decision, provides, particularly in times of extensive uncertainty, a feeling of security and self-balance.

Alienation:

Consumption sphere and being busy as normative reference for the self and normative narratives how to behave as Brazilian

According to Fromm and Rosa, the necessity to define oneself by the possibility of buying goods can be linked to alienation as well as the subjective equation of activity and participation in product-related busyness. In this sense, consumption has to be understood as strongly related to the sphere of work: Despite experiencing a global health crisis with different challenges, one of the greatest difficulties for respondents was the inability to work and to feel productive without being busy due to external demands. This is emphasized by respondents like Natalia (66): "corona left me paralyzed [...] I left one (job) and went to another. It is preventing me from working. I had to be calm, because there is no point in getting out of control". Elaine, a 26-year-old master's student, mentioned the need to feel productive and linked it to the absence of institutionalized demands, something that was reported by several other interviewees:

\begin{abstract}
I'm a lot less productive than I would like to be. I have master's activities to do, but it's hard, because you stay in, in almost limbo, you stay... watching social network, watching series, but you're worried about same time and you have to be productive, but you don't have the head to be productive, because you're worried and, anyway, I wake up, like, I can't sleep early because I'm anxious, then I wake up late, then... my meals are not right on time, I try to eat them all, but they're not exactly like normal, ordinary hours. And ... and that's it, like you're in limbo, waiting for it to pass (Elaine, 26).
\end{abstract}

A recurring view that most respondents had in our interviews is that Brazilians, like companies, need to adapt to the new normalcy and reinvent themselves to remain active and even survive the new pandemic context. According to Natalia (66), stores need to be entrepreneurial and need to "reinvent themselves, recreate". Similar to the expected behavior of stores, the individual also needs to be reinventing himself. João (26), a health insurance salesman said that during the pandemic his business grew $200 \%$ and, according to him, this was due to his adaptation to the digital environment. He said that a person staying at home needs to be reinventing his work and his business: 
You have to reinvent your work methodology, not only in the private sector, everyone is reinventing themselves. Every change that generates results comes to add up, what is happening is a way to discover that we can do business using other platforms. The situation is that those who have become digital, who are adhering to this type of context, are the ones who are really out ahead (João, 26).

Amanda, a self-employed trade representative, also thinks similarly. She stated that the extra time people have at home can be used to improve skills and knowledge related to work, so that people are prepared in the event of a new pandemic or world crisis:

Especially because if a similar situation happens like the one we are experiencing today, we have to look for alternatives, so I was already thinking about it, doing other things and looking for knowledge, looking for other ways, ways of doing my job (Amanda, 49).

By distancing themselves from the public sphere, which is experienced as corrupt and inefficient, and by emphasizing that they have to adapt and assert themselves as individuals, people take responsibility for their own fate without recognizing the social side of it. Especially if they see themselves as entrepreneurs of their own selves, there is a danger that they will become the cogwheels of a machine in Fromm's sense, without understanding this alienation. This is perceived, for example, in the discourse of João (26), when he disconnects the effects of a world health crisis and links the success of his business, which is after all a health insurance company, to his own ability of adaptation. The necessity of social change is lost sight of; instead, the value of fellow human beings is also assessed by their personal willingness to adapt, change and readjust. This view is linked to a naturalization of social inequalities (Souza \& Mattos, 2007; Souza, 2008), turning social processes that lead to inequality invisible by references to natural developments.

I would say that we are going through a process of natural selection where the strongest are surviving. I don't know, sometimes I believe in conspiracy theories that this virus was injected into society, sometimes I don't, but if I found someone today from space, I would say that the world is going through a process of natural selection. Where the strongest will stay and the weakest will go away (Denise, 26). 


\title{
Belonging and Identity:
}

Consumption and looking for belonging between

empowerment and status arrangement on a low level

We have found that consumption in the sense of a possible empowerment can contribute to a sense of solidarity with others and that new social groups are emerging that can influence public life. However, an analysis of consumption during the pandemic shows how it helps people to come to terms with the status quo on an individual level instead of critically reflecting on social developments and actively seeking to change them. Power differences of a capitalist system are not fundamentally questioned in this case. In the sense of a critical social psychology following Fromm's and Rosa's work, it can be shown that participation in a consumer society is at the forefront of consciousness and as a goal becomes the focus of one's own activities, while social role structures and associated institutional orders are hardly addressed.

Empowering consumption:

Helping each other, providing feelings of solidarity

Consumption is a social act. Through consumption, people can identify their social roles, integrate into a society, and feel that they belong to a group. At the time of crisis in the Covid-19 pandemic, we could see that individual identities were also shaped by a wave of collective identity aimed at solidarity. Several respondents said they believe that the society is on its way to become more supportive, in addition to reporting cases where they are helping others. Vitória (60), for example, stated that she recognized change in society and hoped it turned out to be a positive consequence of the pandemic for Brazil:

\begin{abstract}
I even see that the political parties of the left-wing have as their goal today to help others. They give basic food, these things, so the change was the appreciation of the human being. That we were a little forgetful of each other, right? Everyone just thought about themselves, now I noticed that society itself is more concerned with others. It is doing wonderful things for other people (Vitória, 60).
\end{abstract}

The interviewee continues to affirm that the human being is responsible for the transformation of the world and introduces in her narrative the role of God in the pandemic: 
the world through people, it is not nature itself that changes anything, it is the man that transforms thoughts, the understanding of things, it is the man that transforms everything, and it can either improve the living situation or it can make it worse, so I believe that if there is goodwill, everything can change (Vitória, 60).

One of the expressions of solidarity was linked to purchases via food apps. Roberto, a 57-year-old public employee, claimed to be ordering more food to be delivered to his home using applications for that purpose: "it is also a way for you to bring resources to these people who are there to make delivery and to provide this service from end to end, right". Similarly, Matheus, a 20-year-old student who lost his job during the pandemic, also stated that he is often ordering food via apps: "We can kind of eat and help small restaurants not to break, you know. So, there is this side. I think I'm consuming a lot of Ifood".

Respondents also demonstrated their solidarity through collective identity identification. The narratives of "we are all in the same boat" (Vitória, 60) and "we are together in this fight" (Natalia, 66) appeared frequently in the interviewees' speech. According to Amanda (49): "coronavirus made people equal, so it puts people on a level where everyone will go through this". Respondents believe that Brazilians are sharing the pandemic experience together, and this strengthens the spirit of nation and collective identity. For Vitória (60):

The Brazilian nation [...] Today we are at the same level, in the same concept, within the same bubble, because we are all living the same thing, rich, poor, middle class, low clergy, high clergy, everyone on the same level, on the same boat. We can all die of the same disease, in a matter of minutes, the matter of nation, is a single nation (Vitória, 60).

Thus, we realize that for several respondents there is a shared conception that all Brazilians, regardless of social class, are equal, experiencing the same challenges within the health crisis, like the possibility of falling ill and dying due to the disease.

Consciousness in consumption manifested itself in two aspects. Firstly, respondents showed that they felt responsible for helping small producers and businesses. Luísa (20) stated that she is now aware that small businesses need the neighboring community most and that she has avoided shopping in large markets and shopping centers. Secondly, the participants also exhibit responsible behavior toward other people. None of the interviewees claimed to have stocked purchases. On the contrary, in general they condemn the stock practice and consider it a selfish act. The spirit of solidarity is clear in the words of Sarah, a 28-year-old doctoral student: 
When I go to the market [...] I don't buy ten thousand things from the same item. For example, I buy a lot of vegetable milk, now I buy less than before, even if I have to go to the market more often [...] I think more about others when I go shopping. And that's kind of stupid, maybe, but for me not to feel selfish, I prefer to buy, for example, if there is a cheese on sale and that everyone buys and a another cheese a little more expensive, I prefer to buy maybe the more expensive one because I know that is not what most (of people) will buy. I'll leave the cheaper cheese for others (Sarah, 28).

This kind of wish for solidarity could be understood as part of a transformation process to a more humane society. As pointed out by Fromm, this change can only emerge as a bottom-up process and not as a result of bureaucratic orders. In this sense, it is necessary that human beings become connected within groups and organizations to overcome their anxieties. Being aware of the social problems, an interconnected population could consciously make decisions that concern the society's affairs. Facing a high level of uncertainty during the pandemic, in our interviews we found out that hope is related rather to bottom-up processes than having the state as an actor. This could be observed in the statement of Vitória (60) below:

I even see that the political parties of the left-wing have as their goal today to help others. They give basic food, these things, so the change was the appreciation of the human being. That we were a little forgetful of each other, right? Everyone just thought about themselves, now I noticed that society itself is more concerned with others. It is doing wonderful things for other people. [...] I can imagine, and I see, and I hope I am not mistaken, a transformation in society, in relation to others, more friendship, more connection, more protection, and help, you know? I believe that people at first become more fraternal, more friendly, to help each other. But if you're going to get used to it and go back to what it was before, I don't know, selfishly, to do what you wanted to do. I don't know, but as soon as I get out of this situation, I believe that the concepts will turn more to fraternity. Having a more fraternal world and society (Vitória, 60).

Consumption as means of status arrangement:

Cultural rather than institutional framings

Indeed, no statements in our corpus of research emphasized the role of the state in assisting companies and citizens to survive the pandemic. Rather, the normative narrative was stressed that being Brazilian implies the need to be creative and look for solutions, even if what is happening is a complex global economic crisis. The concepts of individual flexibility and personal readiness to help are rather empha- 
sized than the paths paved by institutions toward a more just society. Neither the role of the state, nor of institutions in the problem- solving aspects of the pandemic were raised, but the responsibility was driven to the individuals themselves. Consequently, the idea of fraternity comes from people helping each other, not from the ideal of an equal society. The discourse of 'us all in the same boat' supports people not to reflect on structural inequalities and their institutional embodiment, but to focus on their private life rather than on the public sphere.

As kind of an arrangement with an unequal Status quo rather than a fight for change, we can observe a naturalization of suffering and struggling when being Brazilian is linked to pride over the ability to adapt even to misery without 'stopping to dance'. In the same way, we understand attempts that claim God's responsibility for the pandemic and its social outcomes - an implicit naturalization of equalities within the society without framing them as social. As pointed out by Souza (2020), considering Max Weber's understanding of the religious discourse as a particular way of economic and social domination, religion may become a means of reproducing social inequality, naturalizing certain forms of oppression and domination.

Status arrangement can also be associated with a rather resigned view of belonging to the Brazilian nation, which makes other countries appear idealized and, in this context, makes one's own scope for action appear limited. In this sense, several participants criticize the Brazilian "way of life" and point out what the citizens do wrong in the country. João (26), for example, compared the outcomes of the pandemic in Brazil and Germany and Brazil and the USA. He stated that Germany dealt really well with the pandemic because of its discipline, meanwhile "Brazilians are not disciplined, 200\% undisciplined, totally inconsequential" (João, 26). When talking about the USA, he said: "I am jealous of the American nation for the discipline they have, for the feeling of belonging, they are an example to the whole world, in terms of nationalism, which really makes a difference". Lastly, according to Denise (26): "we Brazilians are not obedient, it only works by force". From this perspective, being in one boat with the other Brazilians seems more like a burden than a chance for common ground.

\section{Control and Identity:}

Consumption between agency and fragmentation

Especially in times of insecurity and facing the imperative to stay away from other people, consumption can create a possibility to experience oneself as an agent despite adverse circumstances, as someone from whom not all reins have been taken away, but who can still make decisions and has not completely lost control over 
one's own life. In this sense, consumption can at least temporarily offer a counterweight to reduce one's own anxiety. On the other side, Fromm pointed out that consumption can also lead to a permanent avoidance of precisely this confrontation with one's own discomfort. Especially in the face of a worsening crisis in times of pandemics, is a danger of fragmentation, which can also be understood in connection with the consumption sphere by providing fears of social exclusion and feelings of emptiness and loneliness. By seeking responsibility for the course of one's own destiny within oneself and also evaluating other individuals from this perspective, pressure that can be directed at oneself and at others arises from the effort to adapt to new circumstances.

Consumption as Agency:

The internet as the new shop display and

eye-catching shopping as a way to maintain control over life decisions

Given the lockdown, the number of places to shop and have personal contacts was very limited. This posed a great challenge to consumption and was accompanied by feelings of loneliness, isolation and powerlessness in some respondents. Several times in the interviews it became clear how the internet not only functionally filled this gap, but also served emotionally as a space to feel one's own effectiveness and involvement and to reassure their own ability to act.

A way to gain control over life in the context of the pandemic was by increasing eye-catching shopping and increasing consumption of differentiated products. Most respondents said they downloaded purchase apps on their smartphone after social isolation began. As the interviewees could no longer visit physical stores (except for market and pharmacy), they started to access on-line stores more frequently:

\footnotetext{
I downloaded the app from Amazon, I downloaded clothes apps, I think about five, I downloaded the Aliexpress app, I downloaded several shopping apps and I kept looking, looking, looking, my hand hurt, you know? Then I ordered. [...] Every day I wanted to buy something (Sarah, 28).
}

Sarah (28) stated that she started to access on-line shopping websites daily and at the beginning of the pandemic she made some impulse purchases, but at the time of the interview she was already selective, saving money. This behavior is similar to that of Elaine (26), a Master's student:

Sometimes I spend all day looking at shopping websites and things like that, not that I actually buy, but... anyway, I keep seeing a lot, 
I feel like buying for... I know what kind it is, yeah a purchase ... really ... how do you call it? it is not a rational purchase, it is an... impulsive purchase [...] But I resist the impulse (Elaine, 26).

Some respondents indicated that they started to order more from food delivery apps to bring different meals into the home. The choice of products different from the ones usually bought by the respondents was a purchasing behavior also identified in the interviews. Sarah (28) claimed to be interacting more with the products on the market in order to try something new and Sofía (22) reported that:

It also changed the way we shop, for example, shopping was a very, very, very specific thing, [...], (now) when we see, we are already grabbing something [...] that normally we wouldn't take it just because we want to try it, because we're not doing anything [...] And it ends up changing because we... it's kind of an attempt to bring something different, like, to everyday life (Sofía, 22).

In general, we realized that although the days in social isolation were similar, differentiated products had the ability to bring something new to people's homes. Furthermore, taking into account the context of uncertainty about the future and the inability to have control over the pandemic, consumption served as an escape, allowing individuals to be entertained, have choices and make decisions about their own lives, passing on a feeling of relief in the midst of the crisis.

\section{Fragmentation:}

Trying to avoid to feel lost and socially

excluded from consumption possibilities

Still, as Fromm and especially Rosa point out, being able to buy products does not provide feelings of resonance when people are not able to build a relationship to these products. The repeated purchase of individual goods can lead to a feeling of a lack of self-efficacy and fragmentation, especially if this does not eliminate one's own anxiety permanently, but at most in the short term. On the contrary, the perceived dependence on the possibility of being able to make new purchases increases- and makes people feel insecure.

The less secure one's own income is, the more threatening one's own dependence and integration into the consumer sphere becomes. People feel under pressure and face the danger to feel socially excluded, to lose their status and control over their own life. Paulo, 33, a public employee and president of a transport cooperative, said the cooperative has not worked since the beginning of the pandemic due to 
the new restriction measures. So to help with the family bills, his mother started sewing and selling masks and he has been studying on-line shopping websites (like Wish and Aliexpress), looking for parts and accessories that can be bought and resold if he needs to change in the event of "things get more complicated in the future". Again, an imagined national mentality is linked to a normative narrative about not losing control under pressure, but making use of Brazilian creativity to find solutions:

[...] As it is happening now and, if there is more to come, we will have to face it, it does not mean that I did not want to be Brazilian, I want to be Brazilian. Brazilians are very creative. We will find a way out of this pandemic, this sadness (Vitória, 60).

For Laura, the concern about not being able to work comes from another source. She is a housekeeper and feels distressed about not having the money to meet her financial responsibilities:

\footnotetext{
It's difficult, because for those who have a, let's say, a normal life, that has a job to count on, but for people who are going to fight, then this thing of staying at home with the bills arriving and with things to pay with financial difficulty, it is hard. The mind starts to get worried. And we get anguished because we can't do anything. From yesterday to today, I was in a bad place (Laura, 52).
}

Suzanna (26) also expressed concern about financial difficulties. She fears having to ask someone for help, which makes her troubled: "When I stopped working, that's when I said: "Damn! so it's serious". The financial aspect is really shaking me, not working and not being able to pay for my things". Conversely, for the interviewees who have salary security, the quarantine period has been one of greater rest, decreased work rhythm and greater enjoyment of the family members. This shows how important it is to take social differences into account when analyzing the effects of the pandemic.

\section{Conclusion}

After exposing our critical understanding of the results, we present in Table 2 the $A B C$ of identity and consumption created from aspects identified in the pandemic narratives of the interviewed Brazilians. When (re)building their identity through the search for authenticity, belonging and control, we propose that the symbolic meanings of consumption in the identity construction were found to be ambiguous and we can understand them in two dimensions, as seen in Table 2. 
TABLE 2

THE ABC OF IDENTITY

\begin{tabular}{|c|c|c|c|}
\hline Authenticity & Belonging & Control & Effect \\
\hline Alienation & $\begin{array}{l}\text { Keep below/ } \\
\text { Status arrangement }\end{array}$ & Fragmentation & \multirow[b]{2}{*}{ 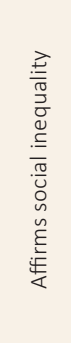 } \\
\hline $\begin{array}{l}\text { Self-images linked to normative } \\
\text { narratives how to behave as a } \\
\text { Brazilian. } \\
\text { Consumption sphere as a norma- } \\
\text { tive reference that is needed to } \\
\text { have a feeling of self. }\end{array}$ & $\begin{array}{l}\text { No questioning of normative to } \\
\text { deal with the situation as an indi- } \\
\text { vidual, no questioning in the role } \\
\text { of the state, accepting capitalist } \\
\text { order as a natural order. } \\
\text { Losing part of social identity when } \\
\text { not feeling busy and being able to } \\
\text { work. }\end{array}$ & $\begin{array}{l}\text { Individualized understanding and } \\
\text { trials to readapt. } \\
\text { Feelings of being lost and lonely } \\
\text { facing the shutdown and social } \\
\text { exclusion of consumption worlds. }\end{array}$ & \\
\hline Engagement & Integration & Orientation & \multirow[b]{2}{*}{ 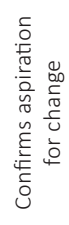 } \\
\hline $\begin{array}{l}\text { Responsible, more reflected and } \\
\text { sustainable way of consumption. } \\
\text { Being part of a change that leads } \\
\text { to a more reflexive and healthier } \\
\text { lifestyle. }\end{array}$ & $\begin{array}{l}\text { Solidarity rises, new groups - } \\
\text { building the potential for a new } \\
\text { understanding of one's own social } \\
\text { role. }\end{array}$ & $\begin{array}{l}\text { Consumption as a means to feel } \\
\text { in control, to have choices and to } \\
\text { have impact. } \\
\text { Consumption as a means to deal } \\
\text { with own anxieties. }\end{array}$ & \\
\hline
\end{tabular}

Source: Authors (2020).

Our study evinces that the pandemic encourages people to reflect on their consumption. This is certainly associated with signs that can be seen as hopeful from the perspective of a critical social psychology. These include the emphasis on the responsibility as a consumer for sustainable social development as well as the experience of solidarity and the formation of new identities, which could form the basis for future political endeavors. Different modes of consumption are possible, e.g. a reflexive consumption of regional products in order to strengthen and promote regional traders, from a social identity perspective also in order to feel part of the community, not feeling isolated, but as a productive piece of a whole.

In contrast it also becomes clear how, even in times of pandemics, consumption contributes to the reproduction of social inequality and even leads to polarizations within society becoming more significant. We were able to critically analyze the individuals' consumption narratives that helped to affirm social inequalities in Brazil during the pandemic.

We have discussed responsible consumption as a way of feeling part of society and the community. It was understood as a way of feeling supportive and "not selfish". Though on one hand we can see some signs of a changing consumer consciousness that might serve as a base for transformation processes within the society, on the other hand it stands out that people feel responsible for other people and small businesses without mentioning the responsibility of the institutions. This goes hand in hand with a negative and resigned view of the state, which one does not 
trust and from which one no longer expects anything. It's seen as part of normalcy that public money was going to be stolen by public representatives, there is no confidence in the politicians. As a consequence, class differences and structural power gaps inherent in capitalistic societies disappear from the focus of interest, as people are socialized to deal with their individual and personal life only and there is hegemonic liberal discourse in public: If you work, you get there - framing social integration as a personal problem.

However, we were only able to include a small section of the population in our study. Further analyses are necessary, particularly in order to differentiate the results according to social groups such as class, gender or ethnicity. As a qualitative study, we do not claim statistical representativeness and cannot say anything about proportions. Nevertheless, our in-depth analyses have enabled us to identify areas of tension in society from a critical perspective. These areas are also of importance beyond the subgroup we are investigating and should be taken into account in further analyses of the consequences of the pandemic and social transformation processes. Therefore, by applying a critical lens for the analysis of the phenomenon of consumption, our findings can represent interesting contributions to a critical sociology and the thematic field of identity, both from a Critical Social Psychology and a Consumer Culture perspective.

From our critical perspective, we can observe a reinforcement of class inequalities related to consumption and the inclusion in the work sphere. Whereas for many rather poor people in Brazil, the possibility to work even within the pandemic is a matter of survival, as they need the income to buy food, for richer people there is scope and opportunity to reflect on one's own role in society free from existential constraints. These findings show the extent to which normalcy continues to be unjust during and after the pandemic. This must be taken into account in any case when speaking of "new normalcy", which in this sense may even lead to an increase in social inequalities - even more if we take the global dynamic into consideration. When analyzing social change processes, efforts by citizens to contribute to a transformation toward a more solidary and responsible society through consumption must not be made invisible and neglected.

We end our article with a quote by Fromm that synthesizes the power and role of consumption nowadays and how consumers have the possibility to take a stand and cause a revolution in the capitalist system.

To put it in a nutshell: up to now the consumer has permitted and even invited industry to brainwash or control him. The consumer 
has a chance of becoming aware of his power over industry by turning around and forcing industry to produce what he wants or suffer considerable losses by producing what he rejects. The revolution of the consumer against the domination by industry has yet to come. It is perfectly feasible, unless industry takes control of the state and enforces its right to manipulate the consumer. Fromm (1968/2010: 126).

\section{References}

ARNOULD, E. J.; THOMPSON, C. J. Introduction: consumer culture theory: ten years gone (and beyond). Consumer Culture Theory, v. 17, p. 1-21, 2015.

. Consumer culture theory (and we really mean theoretics): dilemmas and opportunities posed by an academic branding strategy. Research in Consumer Behavior, v. 11, n. 3, 2007.

ASONYE, C. There's nothing new about the "new normal". Here's why. World Economic Forum. June 5, 2020. Available at: <https://www.weforum.org/agenda/2020/06/theres-nothing-new-about-this-new-normal-heres-why/> Accessed in: Oct. 5, 2020.

BLANCHÉ, U. Kultur und Kommerz bei Bansky und Damien Hirst. Bielefeld (DE): Transcript, 2012.

BOURDIEU, P. Distinction: a social critique of the judgement of taste. Cambridge (MA): Harvard University Press, 1982.

BRAUN, V.; CLARKE, V. Reflecting on reflexive thematic analysis. Qualitative Research in Sport, Exercise and Health, v. 11, n. 4, p. 589-597, 2019.

. Using thematic analysis in psychology. Qualitative research in psychology, v. 3, n. 2, p. 77-101, 2006.

BRIGGS, D.; ELLIS, A.; LLOYD, A.; TELFORD, L. New hopes or old futures in disguise? Neoliberalism, the Covid-19 pandemic and the possibility for social change. International Journal of Sociology and Social Policy. Accepted/in press, 2020.

BUBLITZ, M.; CZARKOWSKI, N.; HANSEN, J.; PERACCHIO, L.; TUSSLER, S. Pandemic reveals vulnerabilities in food access: confronting hunger amidst a crisis. Journal of Public Policy \& Marketing, published on-line May 28, 2020.

CROCKETT, D.; GRIER, S. A. Race in the marketplace and Covid-19. Journal of Public Policy \& Marketing, published on-line May 28, 2020. 
DOLBEC, P.-Y.; FISCHER, E. Refashioning a field? Connected consumers and institutional dynamics in markets. Journal of Consumer Research, v. 41, n. 6, 2015.

DW. Como o novo coronavírus acentua as desigualdades sociais no Brasil. Apr. 2020. Retrieved from: <https://www.dw.com/pt-br/como-o-novo-coronav\%C3\%ADrus-acentua-as-desigualdades-no-brasil/a-53256164>. Accessed in: Sep. 13, 2020.

EHNIS, P.; BECKMANNS.; KÜHN, T.; MOHR, M. Gesellschaftlicher Wandel und personale Identität in der Spätmoderne. Von der Schwierigkeit, Wandel und Persistenz gleichermaßen zu erfassen. Psychologie und Gesellschaftskritik, n. 2-3, p. 151-170, 2015.

FOLHA DE SÃO PAULO. "Nas classes D e E, 51\% perderam metade da renda ou mais na pandemia". May, 2020. Retrieved from: <https://www1.folha.uol.com.br/empreendedorsocial/2020/05/nas-classes-d-e-e-51-perderam-metade-da-renda-ou-mais-na-pandemia.shtml>. Accessed in: Sept. 14, 2020.

FROMM, E. My own concept of man. Fromm Forum, n. 17, p. 5-10. 1969-2013. Retrieved from: <https://www.fromm-gesellschaft.eu/images/pdf-Dateien/1977g-eng.pdf>. Accessed in: Oct. 5, 2020.

. The revolution of hope. Toward a humanized technology. New York: American Mental Health Foundation, 1968-2010. . To have or to be? New York: Harper \& Row, 1976. . The sane society. New York: Rinehart, 1955 Escape from freedom. New York: Farrar \& Rinehart, 1941

FUNK, R.; MCLAUGHLIN, N. (Eds.). Towards a human science: the relevance of Erich Fromm for today. Gießen (DE): Psychosozial. 2015.

FUNK, R.; KÜHN, T. (Eds.) Putting society on the couch. Fromm Forum, 23e, Special English Edition, 2019. Retrieved from: < https://www.fromm-gesellschaft.eu/index. php/en/publications/fromm-forum-english/657-fromm-forum-23-2020>. Accessed in: Oct. 5, 2020.

KEUPP, H.; AHBE, T.; GMÜR, W.; HÖFER, R.; MITZSCHERLICH, B.; KRAUS, W.; STRAUS, F. Identitätskonstruktionen: Das Patchwork der Identitäten in der Spätmoderne. 2. überarbeitete Auflage. Reinbek (DE): Rowohlt, 2002. 
KÜHN, T. Leadership in a digitally transforming social world based on Fromm's humanistic approach. Fromm Forum, 23e, Special English Edition, p. 95-107, 2019. Retrieved from: <https://www.fromm-gesellschaft.eu/images/pdf-Dateien/ Kuehn_T_2019.pdf>. Accessed in: Oct. 5, 2020.

- Kritische Sozialpsychologie des modernen Alltags. Zum Potenzial einer am Lebenslauf orientierten Forschungsperspektive. Wiesbaden (DE): Springer VS, $2015 a$.

. Reproduktion der Ungleichheit im Lebenslauf. In: REHBEIN, B.; BAUMANN, B.; COSTA, L.; FADAEE, S.; KLEINOD, M.; KÜHN, T.; MACIEL, F.; MALDONADO, K.; MYRCZIK, J.; SCHNEICKERT, C.; SILVA, A.; SILVA, E.; SOMMER, I.; SOUZA, J.; VISSER, R. Reproduktion sozialer Ungleichheit in Deutschland, p. 219-243. Konstanz (DE): UVK, 2015b.

. Construction of belongingness in late modernity. National Pride in Brazil from a Social Inequality Research Perspective. In: SULLIVAN, G. B. (Ed.). Understanding collective pride and group identity. New directions in emotion theory, research and practice, p. 161-172. London: Routledge, 2014.

KÜHN, T.; LANGER, P. C. Qualitative Sozialpsychologie. In: MEY, G., MRUCK, K. (Eds.). Handbuch Qualitative Forschung in der Psychologie, p. 361-380. Wiesbaden (DE): Springer VS, 2020.

KÜHNER, A.; PLODER, A.; LANGER, P.C. Introduction to the special issue: European contributions to strong reflexivity. Qualitative Inquiry, v. 22. n. 9, 2016.

LURY, C. Consumer culture. Cambridge (UK): Polity Press. 1996.

MCDONALD, M.; GOUGH, B.; WEARING, S.; DEVILLE, A. Social psychology, consumer culture and neoliberal political economy. Journal for the Theory of Social Behaviour, v. 47, n. 3, p. 363-379, 2017.

PATTON, Michael Q. Qualitative research \& evaluation methods. 3. ed. Thousand Oaks (CA): Sage, 2002 [1990].

RITZER, G.; GOODMAN, D.; WIEDENHOFT, W. Theories of consumption. In: RITZER, G.; SMART, B. (Eds.). Handbook of social theory, p. 410-426. Thousand Oaks (CA): Sage, 2001.

ROSA, H. Die Quelle aller Angst und die Nabelschnur zum Leben: Erich Fromms Philosophie aus resonanztheoretischer Sicht. Fromm Forum, v. 23, p. 144-160, 2019. Retrieved from: <https://www.fromm-gesellschaft.eu/images/pdf-Dateien/ Rosa_H_2019.pdf>. Accessed in: Oct. 5, 2020. 
. Resonanz. Eine Soziologie der Weltbeziehung. Berlin: Suhrkamp, 2016.

. Identität und kulturelle Praxis: Politische Philosophie nach Charles Taylor. Frankfurt am Main (DE): Campus, 1998.

SAAD-FILHO, A. From Covid-19 to the End of Neoliberalism. Critical Sociology, May 29, 2020. Retrieved from: <https://doi.org/10.1177/0896920520929966>. Accessed in: Sep. 17, 2020.

SCHNEIDER, N. F. Konsum und Gesellschaft. In: ROSENKRANZ, D., SCHNEIDER, N.F. (Eds.). Konsum. Soziologische, ökonomische und psychologische Perspektiven, p. 9-22. Opladen (DE): Leske und Budrich, 2000.

SOLTY, I. The bio-economic pandemic and the western working classes. SP: The Bullet, March 24, 2020. Retrieved from: <https://socialistproject.ca/2020/03/bioeconomic-pandemic-and-western-working-classes/>. Accessed in: Sep. 15, 2020.

SOUZA, J. Die Naturalisierung der Ungleichheit. Ein neues Paradigma zum Verständnis peripherer Gesellschaften. Wiesbaden (DE): Springer VS. 2008.

SOUZA, J. A guerra contra o Brasil. Rio de Janeiro: Estação Brasil, 2020.

SOUZA, J., MATTOS, P. (Eds.). Teoria crítica no século XXI. São Paulo: Annablume, 2007.

UN, UNITED NATIONS. Policy brief: the impact of Covid-19 on food security and nutrition. Jun, 2020. Retrieved from: <https://reliefweb.int/report/world/policy-brief-impact-Covid-19-food-security-and-nutrition-june-2020>. Accessed in: Aug. 27, 2020.

VOSWINKEL, S. Gekaufte Wertschätzung? Anerkennung durch Konsum. In: HONNETH, A., LINDEMANN, O., VOSWINKEL, S. (Eds.). Strukturwandel der Anerkennung: Paradoxien sozialer Integration in der Gegenwart, p. 121-154. Frankfurt am Main (DE): Campus, 2013.

WITZEL, A.; REITER, H. The problem-centered interview. London: Sage, 2012.

ZIMMER, B. How normalcy went from misnormer to safe world. The Atlantic. April 10, 2020. Retrieved from: <https://www.theatlantic.com/culture/archive/2020/04/ how-normalcy-became-a-safe-word/609805/>. Accessed in: Oct. 5, 2020. 